\title{
Wspomnienie o Ks. Prof. Stanisławie Kobielusie
}

DOI: https://doi.org/10.21697/an.7933

ROMANA RUPIEWICZ

INSTYTUT HISTORII SZTUKI UKSW

ORCID: 0000-0002-8863-6542

3 stycznia 2020 r. odszedł ks. Stanisław Kobielus SAC (ur. 1939) - profesor wybitny, . wrażliwyiniedostę ną intencją przy woły wanie jego zasług dl nauki, któr są oczywiste, przede wszystkim chciałabym ująć w słowa, kim był dla mnie - jego studentk

Ks. Stanisław Kobielus w Instytucie Historii Sztuki UKSW prowadził wykłady z ikonografii sztuki średniowiecznej. Były one wydarzeniem niemal mistycznym, oczekiwanym przez studentów. Mieliśmy poczucie, że odkrywamy wiedzę tajemną, poczucie że odkrywa nieosiggalna dla przecietnego odbiorcy sztuki.Zajęcia ze sredniowiecznych doktryn artystycznych pozwalały wyjaśnić studentom nieoczywiste powody, dla kt rych uprawiano ją w średniowieczu. Wykłady monograficzne natomiast przybliżały szczegóły, które zazwyczaj umykają: Ksiądz Profesor opowiadał w sposób fascynujący, co i dlaczego pojawia się na grzebieniach liturgicznych i jakie znaczenie mają np. węzly obecne w detalach architektonicznych. Pokazując slajdy objaśniał symnolikę dziet sztuki, wykonując przy tym bolikę dzieł sztuki, wykonując przy tym ob-
razowe gesty. Machał rękoma - niezwykle długimi, ponieważ był bardzo wysokim człowiekiem - co było zjawiskowe i urocze. Niespodziewanie wyjmował z kieszeni drobne skarby, które wręczał przyjaciołom. Prof. Katarzyna Chrudzimska-Uhera wielokrotnie otrzymywała od niego kasztany, a dr Agnieszka Skrodzka ziarenka a dr Agniesz
kardamonu.

Serdeczne relacje nawiązałam Księdzem Profesorem pod koniec studiów w Instytucie Historii Sztuki. Gdy byłam już na studiach doktoranckich, Ksiądz Kobielus pożyczał mi książ̇i, wskazywał na ważne problemy badawcze, a ostatecznie został recenzentem mojej pracy. Na obiedzie doktorskim nie pojawił sie jednak, niespodziewanie znikając wszystkim z pola widzenia. Taki by zresztajego zwyczaj-kiedyśby-

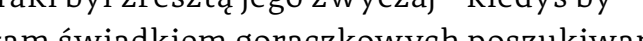
Tar Księdza Profesora po obronie na KUL, gdy wreszcie udało się do niego dodzwonić, jechał już pocią̧giem do Otwocka.

Klasztor pallotynów w Otwocku stanowił jego kryjówkę przed wrzawą świata, przed tłumem, w którym nie potrafił się odnaleźć, przed laudacjami. W październiku 2012 r rozpoczęłam na stałe prace w IHS UKSW i d tamtego czasuczęto bywatam uriędza u Księdza Kobie ja wa Otwocku. Wracajac z wykładów zajeżdżałam do niego na kawę i krótką rozmowę. Dłuższe spotkania były dla Profesora nie do zniesienia, gdy jednak nie pojawiałam się przez miesiąc, dzwonił i zapraszał. Kiedyś poprosił mnie, żeby przywiozła ostre nożyczki, bo trzeba obciąc pryy mu whosy Wiedziazm, ze kontakty zobcymi ludźmi, np. z fryzerem, byly dla niego bardzo trudne. Otaczał go krąg zaprzyjaźnionych osób, przy których czuł się swobodnie. Mieszkał w dwóch malenkich pokoikach. W jednym stało biurko i dwa krzesła. W drugim mieściło się tylko łóżko istolik, pod koniec życia zastawiony lekami. Książki były dosłownie wszędzie - na siegajacych od poth wiedziłam go z dr Izabelą Przepałkowską. Gdy okazało się, że nie mam na czym usiąść, pospiesznie ułożyłam sobie stołek z książek.

Ważnym miejscem w tej samotni by szeroki parapet okienny, na którym stały wazony i kwiaty doniczkowe. Ustawiał je w taki sposób, by nie przysłaniały widoku drzew. Ogromną radość sprawiały mu proste prezenty: pachnące kwiaty, śliwki węre gierki...Na polkach z księzkami można by dostrzec drobne przedmioty - zdjęcia, kamyki, szyszki, obrazki. Przypominały o jego przyjaźniach. Pod koniec życia wszystko to starał się rozdać, opowiadając historię każdego z tych przedmiotów. Te opowieści ożywiały je i nadawały im znaczenie.

Żył bardzo skromnie, uwielbiał saw przyklasztornym ogromic Glęboro odczuwat, ż jego ziemska droga do zbawienia jest praca naukowa. drogą do zbawienia jest praca naukowa. Stanowita dla niego formę moditwy, by przestrzenią, w której spotykał Boga. Uważał, że nie może tracic zbyt wiele czasu na życie towarzyskie, na efektowne wyjazdy zagraniczne, nie przepadał za konferencjami. Miał przekonanie, że Pan Bóg rozliczy go z każdego dnia, z tego, czy wypełni swoje powołanie należycie i przekazał to, co miał do powiedzenia światu. Praca, która

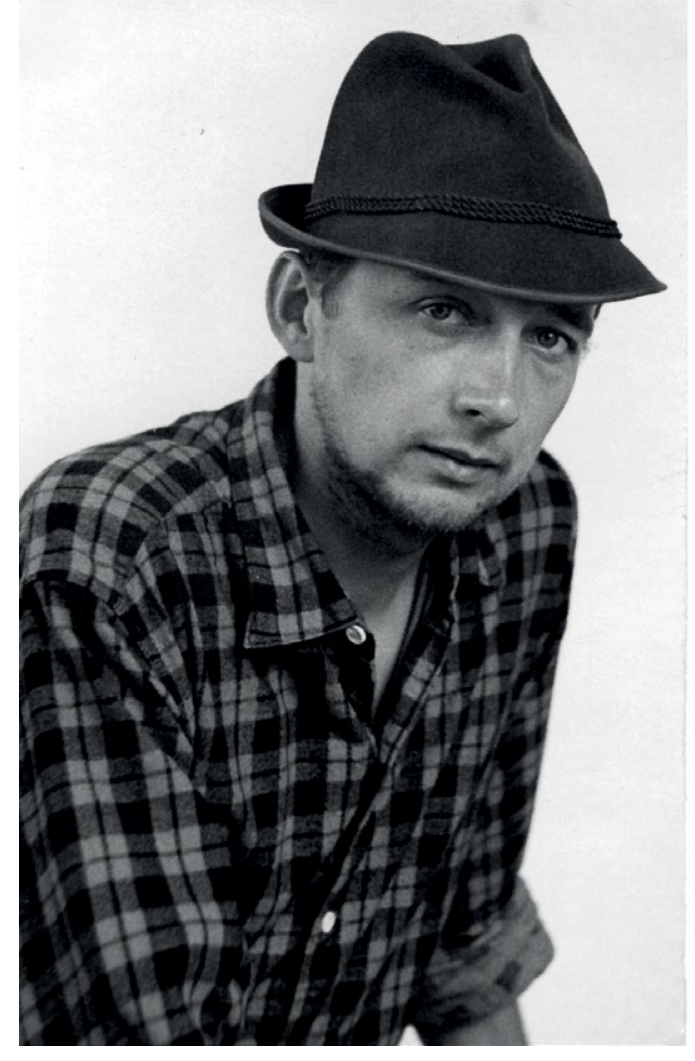

w Kobielus. Fot. z archiwum J. Kobielusa

była dla niego formą modlitwy, przeplatała się w jego codzienności ze zwyczajną moditwą, najchętniej brewiarzową. Zawsze pytał, co u mnie, co piszę, jak się miewa mąz i czy dbam o zdrowie. Kiedyś podarował mi brewiarz, zalecając, bym czytała go tak jak książke - tyle zdań dziennie, na ile czas mi pozwoli. Chętnie opowiadał o zapachach, o ptakach, o kamykach i muszelkach. Mówił poprzez metafory i symbole, czasem trudne do zrozumienia.

Kolejne etapy życia Stanisława Kobielusa nieodłącznie wiązały się z jego badaniami, które owocowały nowymi książkami. Kiedy pisał Lapidarium christianum, kolekcjonował kamienie. Dostawał je od przyjaciół lub rodziny, ustawiał na biurku i parapecie, zachwycał się nimi 


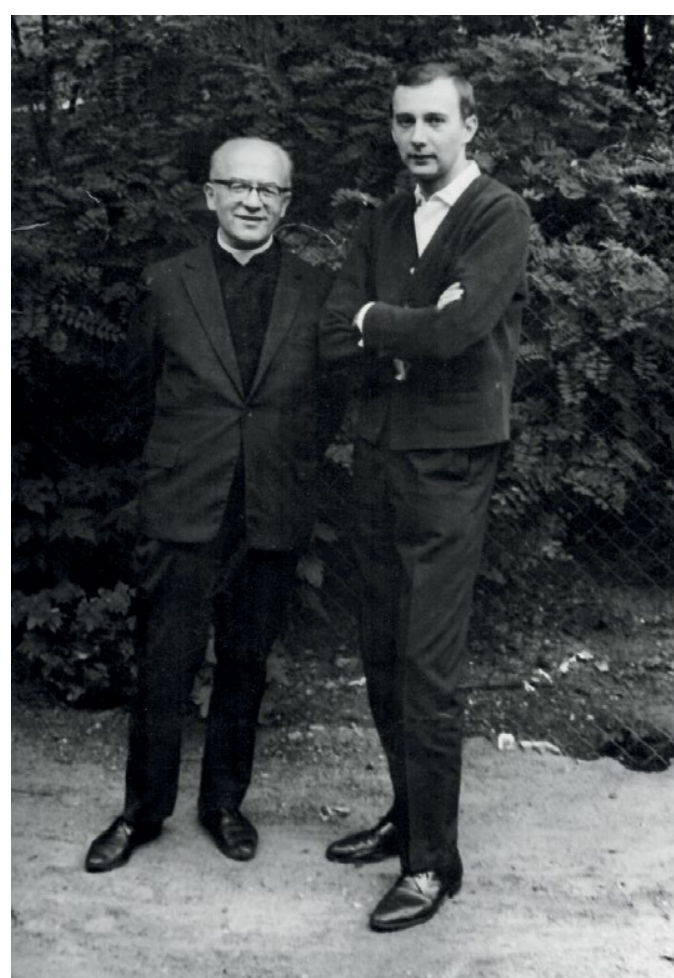

2. Stanisław Kobielus ze swoim stryjem Fot. z archiwum I Kobielusa w rozmowach, które prowadził ze swoim kanarkiem. Pisząc o roślinach, poszukiwał ich na łakach i w ogrodach. Dziękował Bogu za ich nieskończone piękno. W dziełach sztuki średniowiecznej odkrywał przede wszystkim myśl Ojców Kościoła, których pisma czytał namiętnie, najchętniej w językach oryginalnych. Kupował wszystko, co ukazywało się na ten temat, dlatego jego biblioteka składała się w znacznej mierze z dzieł patrystycznych i filozoficznych. Augustyn, Tomasz z Akwinu i Bonawentura towarzyszyli mu na co dzień. Podczas pisania książki Krzyż Chrystusa zachwycił się traktatami De laudibus sanctae crucis Hrabana Maura oraz teologią światła Roberta Grosseteste.

Jego ulubionym miejscem wypoczynku był dom Zgromadzenia Sióstr Sług Jezus w Nałęczowie. Będąc już na emeryturze starał się przyjeżdżać tam raz w roku, na dwa tygodnie. Oczywiście zawsze zabierał ze

sobą książki, siostry miały także podstawowy zbiór literatury pięknej, którą Ksiądz wy zbiór literatury piek Dolnego, gdzie mieszkam, to tylko por goDolnego, gdzie cieszkm, to tylko polgodziny samochodem, zatem częstogo tam odwiedzalam. Chodzilismy na spacery po łąkach i polach, niekiedy zaglądaliśmy do wąwozów. Odwiedzaliśmy też cmentarz w Nałęczowie. Zatrzymywał się przy każdej krowie, każdym nietypowym drzewie, zachwycał się szyszkami i żołędziami, rzeczami prostymi. Dostrzegał w nich dzieła stworzenia. Interpretował kształty $i$ kolory stworzenia. Interpretowa ksz aly i kolory otaczającego go switata przyrody przez pryzmat pisarzy wezesnochrześcijańskich. Najczęściej milczałam, a Ksiądz rozmawi ze swoimi myślami, mówił jakby pisząc wiersze. Doceniałam to, że nigdy nie mówił źle o ludziach, nie oceniał ich i nie obgadywał, nie użalał się. Na swój sposób cieszył się życiem, które przecież często było ciężzkie. Niekiedy dawał odczuć, że cierpi z powodu samotności, braku zrozumionia iakceptacji jego osobowości, nieco szorstkiej.
4. Stanisław Kobielus ze swoją siostra Krystyną, Beskid Sądecki. Fot. $\mathbf{z}$ archiwum J. Kobielusa

Za którymś razem udało mi się namówić go na wycieczkę poza Nałęczów. Mimo nie najlepszego już stanu zdrowia zabrałam go do anowca, mniej zatłoczonego niż Dow zprawiało mu trudności, przysiadał na ławeczce, śmiejąc się, że przez jego wzrost biedne serce tak ciężko musi pracować, by tłoczyć krew w długie ręce i nogi. Cieszył się tą wycieczką jak dziecko.

Najważniejszym miejscem w jego życiu był rodzinny Wieprz, za którym nieustannie tęsknił, oczekując na kolejne, rodzinne spotkania, którym towarzyszyły ogniska z pieczeniem ziemniaków, wspóln giady i dyskusje. Tam czut się najlepej. obiady i dysk je. Tam czu sien njle $W$ jego myślach i poezjl powracał motyw drzewa rosnącego w miejscu, w którym dorastał. Podczas tych pobytów zatrzymyw się albo w rodzinnym domu, albo w pobliskim domu księży pallotynów na Kopcu w Kleczy koło Wadowic. Jego matka, Bronisława, zmarła w 1983 r., w 1997 odszedł jego ojciec, Karol. Miał trzech braci i dwie siostry Najbliższe relacie utrzymyidwie jostry. Namem (ur. 1947) który miszwatz braten Janem (un 19g7) ktory nieszka w Andrychowie. Uwielbiatswoich bratanków - Macieja i Łukasza. Łukasz jest misjonarzem, kapłanem Stowarzyszenia Misji Afrykańskich i mieszka w Togo od 17 lat. Maciej jest pełnym poświęcenia dla ludzi ratownikiem medycznym. Obie siostry ks. Stanisława Kobielusa wstąpiły do zakonu. Maria (ur. 1944) jest pallotynką w Gnieźnie, a Krystyna (ur. 1950) - przełożoną sióstr Zmartwychwstanek

w Castleton, w stanie Nowy Jork w USA.

w Castleton, wstanie Nowy Jork w USA. z siostrami rozmaw al przez telefon niema codziennie. Wielokrotnie byłam świadkiem
tych rozmów, pełnych troski i szacunku. tych rozmów, pełnych troski i szacunku. Siostry dbały o starszego brata. Dostawał od nich ciepłe swetry i szaliki. Nawet jeśli nie były to ubiory na jego gust i miarę, nosił je, by pamiętać o siostrach. Krystyna wysytała mu ze Stanów Zjednoczonych książki, wszystkie których potrzebował do pracy. Ksiądz Profesor pamiętał również o dwóch
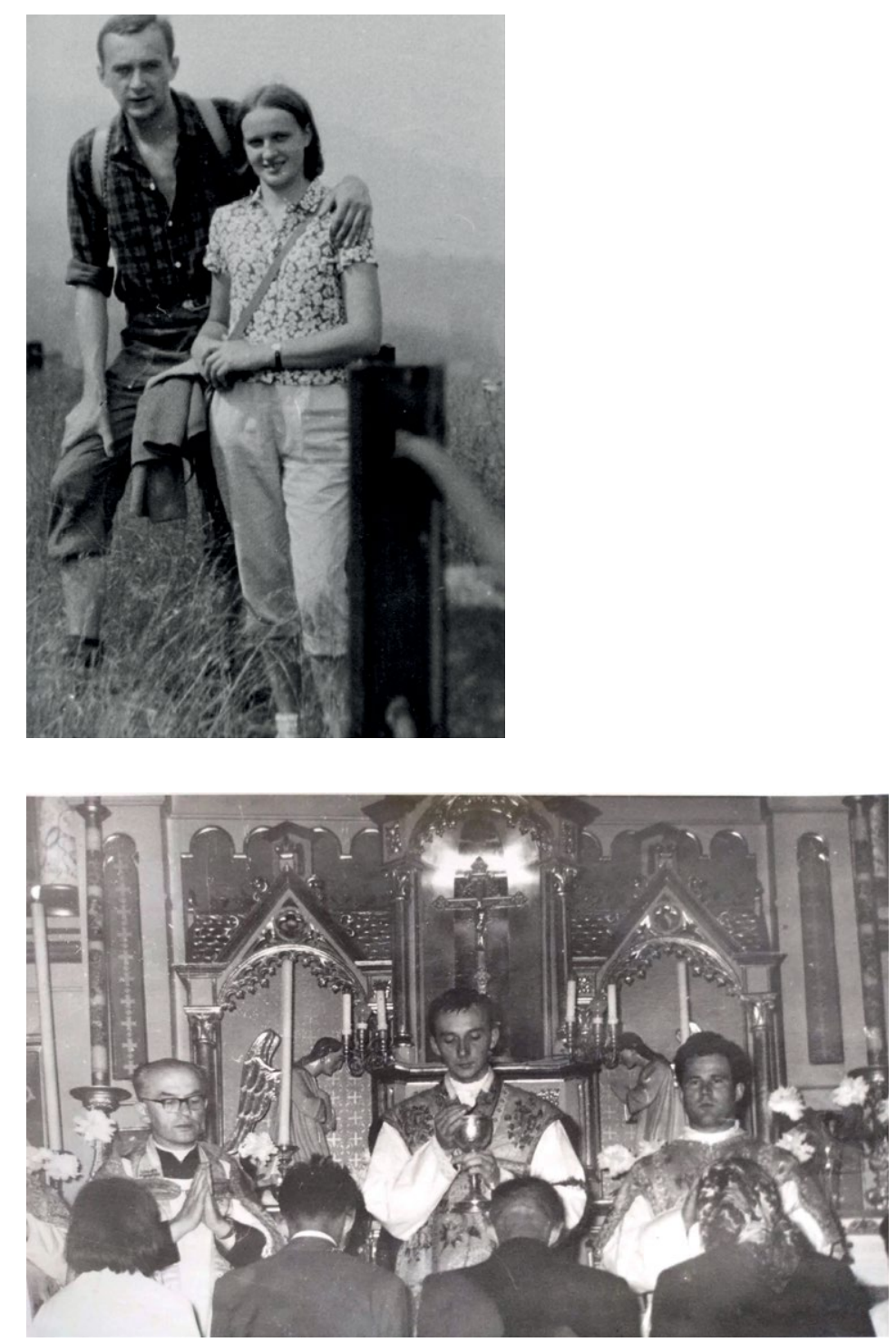

5. Ks. Stanisław Kobielus podczas mszy prymicyjnej. Fot zarchiwum Kobielusa

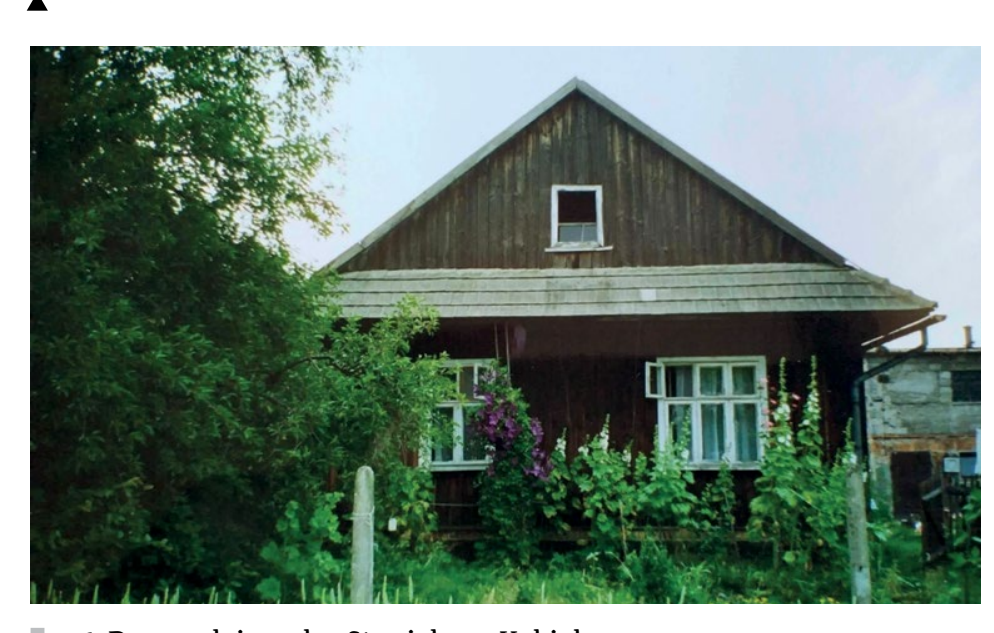

6. Dom rodzinny ks. Stanistawa Kobielus Fot. z archiwum J. Kobielusa 


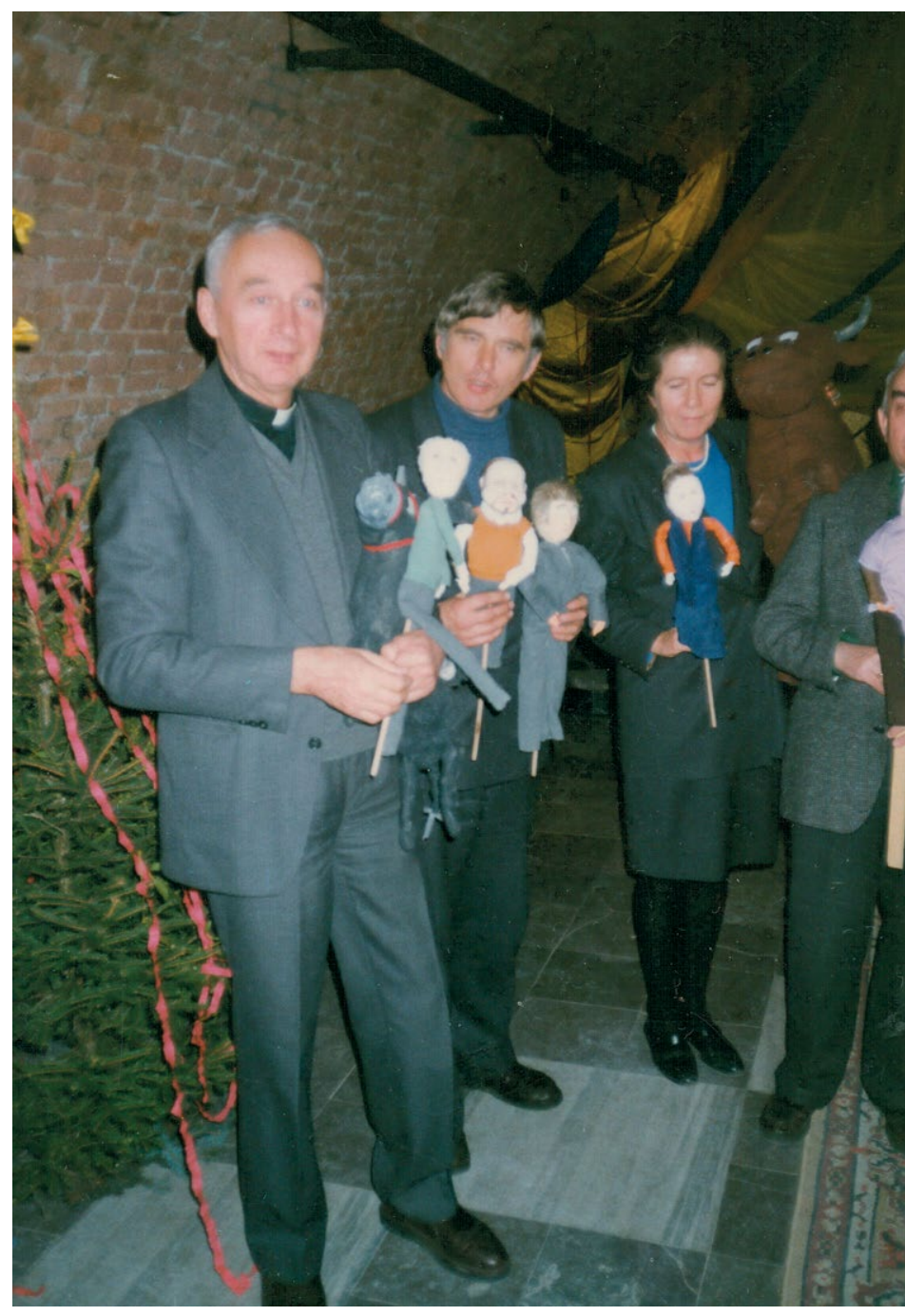

7. Ks. Stanisław Kobielus w towarzystwie prof. Zbigniewa Bani, prof. Kingi Szczepkowskiej-Naliwajek i prof. Andrze K. Olszewskiego podczas spotkania opłatkowego, 1997 .

Fot. $z$ archiwum B. Gutowskiego

pozostałych braciach: Piotrze (1942-2015), mieszkający w rodzinnym Wieprzu,

i Kazimierzu (1940-2018) żyjącym

w Andrychowie.

Ksiądz Kobielus przez całe swoje kapłańskie życie regularnie dostawał od swoich braci i sióstr przy okazji rodzinnych spotkań swojskie przetwory: soki, dżemy, miód, ciasta. Uwielbiał zwyczajne jedzenie, podane w prosty sposób, z warzywami,

które wyrosły na rodzinnym polu. W czasie pobytów w Wieprzu lubił przechadzać się po ojcowiźnie, po polach i lasach Za każdym razem coś z takiej przechadzki przynosit kwiat, gatazke szyszke, liscie ozachilla ga
Jego rodzina wspomina, że długo po każdym spacerze rozkoszował się swymi znaleziskami. Był wrażliwy na zapachy uwielbiał woń drzewa, żywicy świerku czy sosny. W rodzinnym domu zrobił sobie proste łóżko z surowego drewna, z siennikiem, by móc sycić się zapachami natury, które pamiętał z lat młodzieńczych. Często wspominał dawne dzieje, życie na wsi, tamtejsze zwyczaje, przygody z rodzeństwem i przyjaciółmi.

O pracy ze studentami mówił niewiele. Chętnie natomiast wracał myślami do dawnych wyjazdów inwentaryzatorskich, w tórych często to brat, Jan. Razem przemierzali Polskę: klasztory, kościoły i muzea kościelne.

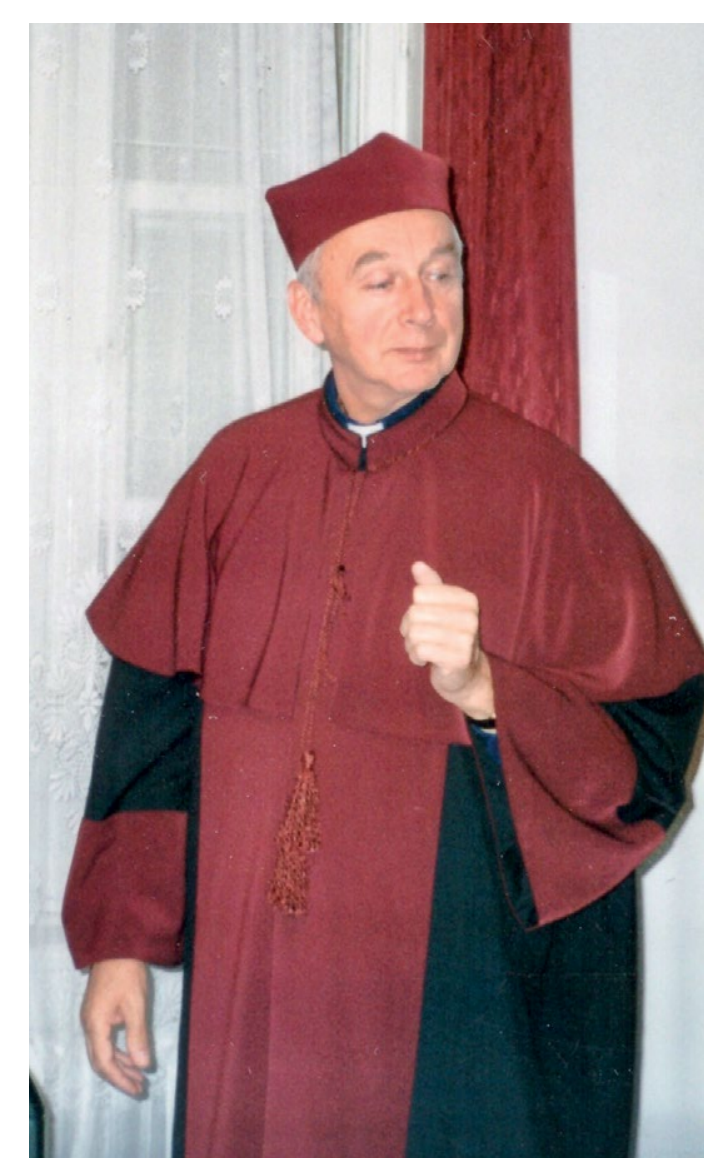

8. Ks. Stanisław Kobielus na UKsW. Fot. $z$ archiwum J. Kobielusa
Brat pomagał mu w fotografowaniu, ustawianiu świateł, był też jego kierowca. Na młode, kształtujące się życie duchowe Księdza Profesora miał wpływ jego stryj, ks. Konstanty Kobielus SAC (19141984), który zmarł w opinii świętości. Rodzina Księdza Profesora Stanisława Kobielusa obfituje w powołania kapłańskie zakonne. Przywołam jeszcze jego ciotkę, Filomenę Kobielus (siostrę jego ojca, Karola) zmartwychwstankę w Kętach. Także córka stryjecznego brata Księdza Profesora, Agnieszka Kobielus, wstapiła do zakonu. Ks. Profesor Kobielus często chorował, a my martwiliśmy się o jego wątłe wat, a my martwilismy się ojego wątle zdrowie. Paniętam, jak kiedys razem z d Agnieszką Skrodzką odwiedzałyśmy go w szpitalu, jeszcze jako studentki. Pierwsze oznaki choroby Alzheimera pojawiły się u Ks. Profesora Kobielusa ok. 5 lat przed śmiercią. Był świadomy, że jego czas dobiega końca. Często o tym mówił i czynił przygotowania do spotkania z Bogiem. Starania dotyczyły przede wszystkim sfery duchowej, ale mýlal tez o tym, co ziemskie. wej, a mysta tez o tym, cozienski

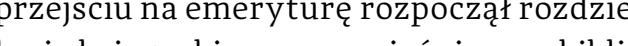
anie księgozbioru zaprzyjażnionym bibliotekom seminaryjnym oraz badaczom, zgod nie z ich zainteresowaniami.

Pracował niemal do końca swojego życia. Po przejściu na pełną emeryturę w 2011 roku ukazały się jeszcze cztery jego publikacje. Jedną z nich jest wspomniane już Lapidarium christianum, poświęcone symbocą naukową je również książka Concordia Novi et Veteri Testamenti. Zapowiedzi dzieła odkupienia ijego spełnienie w teologii i sztuce średniowiecza (Poznań 2013), w której zostały zestawione sceny Starego i Nowego Testament pojawiające się w sztuce jako typy i antytypy. Książka ta przywołuje bogaty materiał źródłowy do badań nad typologią sztuk średniowiecznej.

$$
\text { W } 2016 \text { roku Stanisław Kobielus opu- }
$$

blikował swoją ostatnią, niespełna

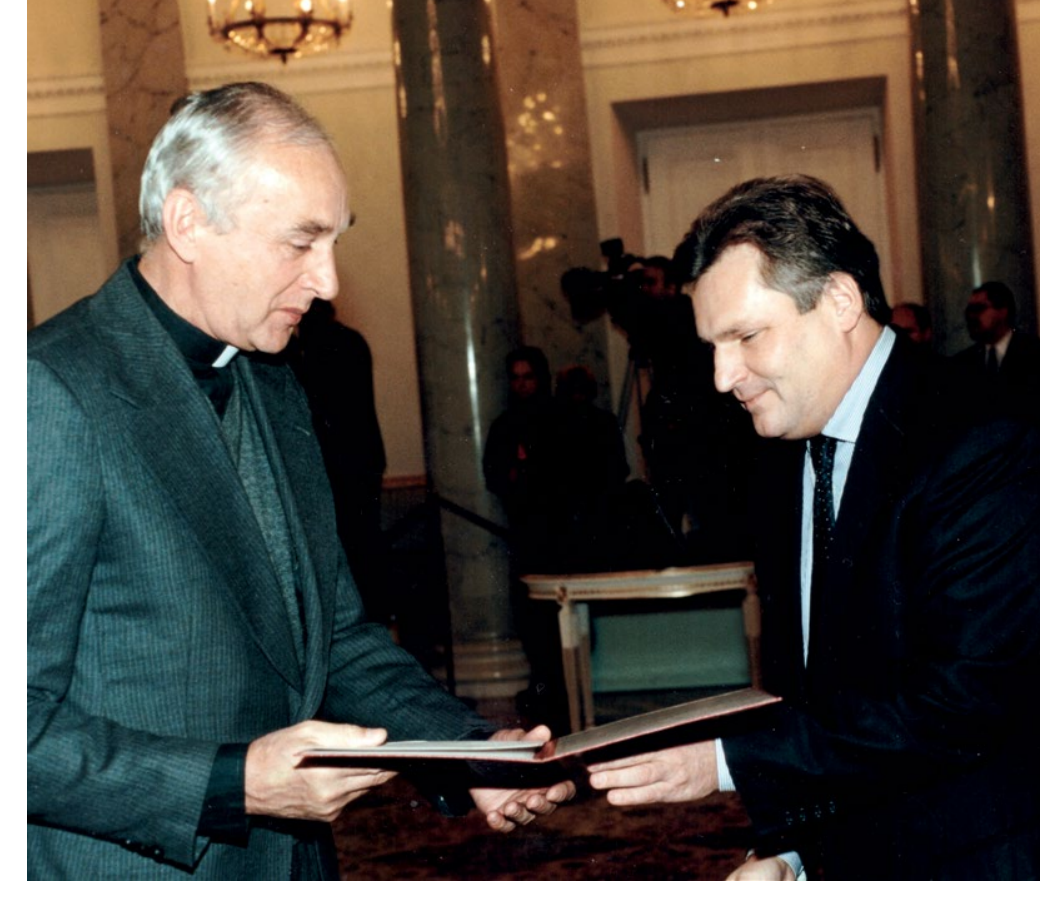

9. Ks. Stanisław Kobielus odbiera nominację profesorską z rąk Prezydenta RP Aleksandra Kwaśniewskiego, 1998 r. Fot. z archiwum J. Kobielusa

100-stronicową monografię Wskrzeszenie Łazarza w teologii i ikonografii. Pisał ją już jako człowiek chory i cierpiący. Łazarz i jego siostry były mu bliskie. W zakończeniu liczącym niespełna 10 ważnych zdań zapisał: „Cud przywrócenia Łazarzowi życia był odpowiedzią Chrystusa na ludzką nadzieję życia wiecznego, będącego uzyskaniem po śmierci trwania w obiecanej ludziom obecności przed Oblicz obiecanej dzioge oraz: "Wskrzeszenie tazarza było nie tylko zapowiedzią zmartwychwstania Jezusa, lecz dawało słuchaczom widoczną gwara cję prawdziwości nauczania Chrystusa o zmartwychwstaniu człowieka i o realiach Królestwa Niebieskiego w perspektywie eschatologicznej". Po ukazaniu się tej książki zaczął spisywać kazania. Każde z nich było poświęcone kolejnemu wezwaniu Litanii Loretańskiej. Zamierzał opublikować je jako cykl, w którymś z czasopism 


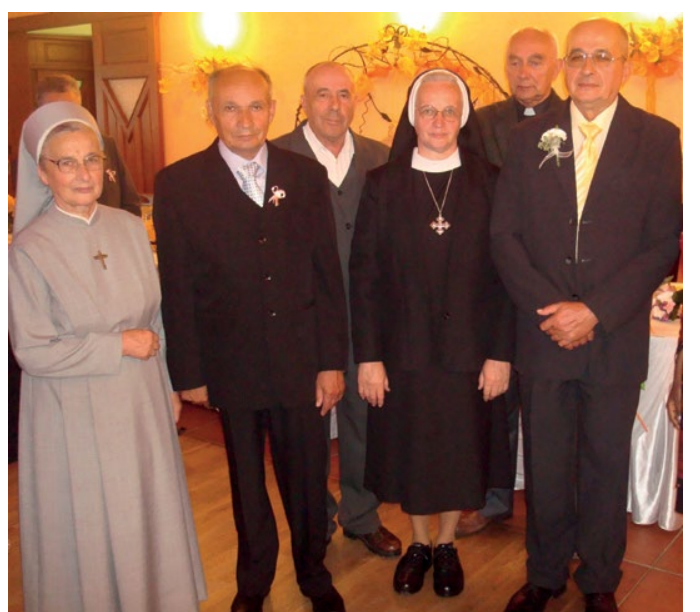

10. Ks. Stanisław Kobielus z rodzeństwem. Od mierz, Piotr, s. Krystyna i laej: s. Maria, Kazimierz, Piotr,

katolickich. Czytał mi fragmenty, ostatnie jeszcze w 2017 r. Nie miały charakteru naukowego, ale jak wszystkie jego dzieła zawierały myśli Ojców Kościoła oraz były przepełnione średniowieczną teologią. Nie udało mu się dokończyć dzieła, które nie zostało opublikowane.

Zapamiętałam go jako człowieka niezwykle wrażliwego, dobrego, pomagającego badaczom, zwłaszcza poczatkujacym. Wielu z nich poznałam osobiście Niczo Wielu z nich pozna asobiscic. Niczego nie gromadzil, wszysthim się dzielił. Już jako emeryt chętnie podejmował się pisan
recenzji, mimo trudności ze zdrowiem. Ostatnie Boże Narodzenie spędzi
Osjie mimo trudnóci ze zdrowiem.

Ostatnie Boże Narodzenie spędził
aśrodku pallotyńskim w specjalistycznym ośrodku pallotyńskim rodzina, bratankowie i ich rodziny. Śpiewal kolędy trzymając go za ręce. Najmłodsze dzieci były przebrane w stroje kolędników. Zmarł otoczony milością wspólbraci oraz kochającej rodziny, przy której czuł się bezpiecznie.

Chciałabym przywołać najważniejsze publikacje ks. prof. Stanisława

Kobielusa, których spis zamieszczam poniżej. Jest autorem 44 artykułów naukowych, poświęconych głównie ikonografi, estetyposwięcon stuki wredniowece i teorii sztuki średniowiecznej, publiko-

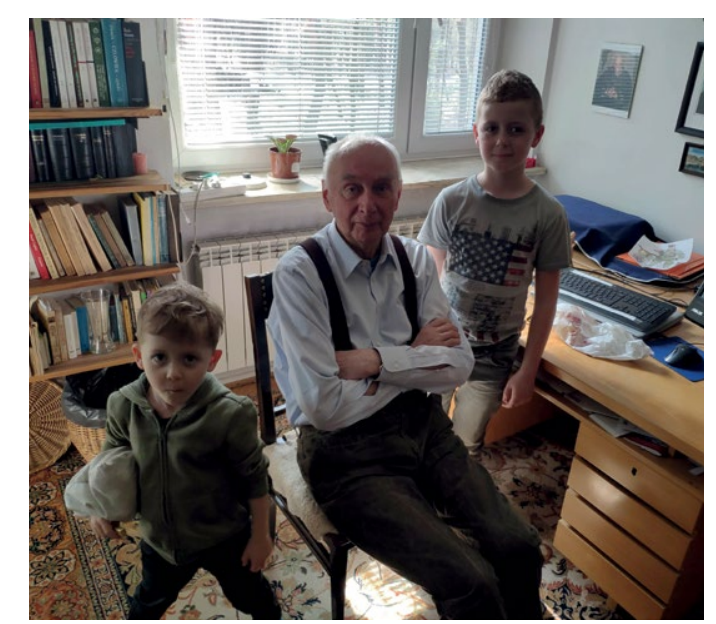

11. Ks. Stanisław Kobielus w swoim mieszkaniu, w towarzystwie wnuków brata, Jana Kobielusa. Fot.zarchiwum J Kobielusa

na łamach czasopism, takich jak: „Folia Historiae Artium”, „Rocznik Historii Sztuki”, ,Biuletyn Historii Sztuki”, ,Acta Universitatis Nicolai Copernici. Zabytkoznawstwo i Konserwatorstwo", „Saeculum Christianum”, „Studia Theologica Varsoviensia”, „Communio. Międzynarodowy Przegląd Teologiczny", Series Byzantina”, „Ethos”, czy „Artifex Novus". Szczęśliwie wszystkie artykuły zostały zebrane i opublikowane ponownie w dwóch tonownie w dwóch tomach (w 2002 i 2015). Ks. Prof Kobielus jest rownież autorem 10 książek monograficznych, z których dwie doczekały się drugich wydań. Przełożył także trzy traktaty średniowieczne, ważne dla historii sztuki. Był poetą, którego wiersze w ostatnich latach stały się przedmiotem badań literackich. Miałam zaszczyt napisać wstęp do tomiku Kto użyczy łez trawom, do którego pomagałam wybierać utwory. W a juz swoj tomik poezli, przeptatn już swój tomik poezji, przepehniony tematami eschatologicznymi, jednak pełnym radości i nadziei na spotkanie $\mathrm{z}$ Panem. W 2010 r. pracownicy Instytutu Historii Sztuki, doceniając ogromny wkład w naukę Księdza Profesora, wydali księgę pamiątkową Jemu poświęconą, w której zawarto również szczegółowy spis prac badawczych Stanisława Kobielusa (Homo Creator et Receptor Artium. Ksiega pamiattowa Księdzu Profesorowi Stanisławowi).

\section{KS. PROF. STANISEAW}

\section{KS. PROF. STANISEAWA KOBIELUSA}

Monografie

Wskrzeszenie Łazarza w teologii i ikonografii średniowiecza, Tyniec 2016

Świątynia Zesłania Ducha Świętego w Otwocku, Ząbki 2014

Concordia Novi et Veteri Testamenti. Zapowiedzi dzieła odkupienia i jego spełnienie $w$ teologii i sztuce średniowiecza, Poznań 2013.

Lapidarium christianum. Symbolika drogich kamieni. Wczesne chrześcijaństwo i średniowiecze, Tyniec 2012.

Florarium christianum Symbolika roślinchrześcijańska starożytność i średniowiecze, Tyniec 2006

Ikonografia zdrady i śmierci Judasza. Starożytność chrześcijańska i średniowiecze, Ząbki 2005.

Bestiarium chrześcijańskie. Zwierzęta w symbolice i interpretacji. Starożytność i średniowiecze, Warszawa 2002.

Krzyż Chrystusa. Od znaku i figury do symbolu i metafory, Warszawa 2000 (wyd. Tyniec 2011).

Człowiek i ogród rajski w kulturze religijnej średniowiecza, Warszawa 1997.

Niebiańska Jerozolima. Od sacrum miejsca do sacrum modelu, Warszawa 1989 (wyd. 2 2004).

Tłumaczenia tekstów źródłowych

Defensorium czyli Średniowieczny traktat o „Obronie nienaruszonego i trwatego o "Obronie nienaruszonego i trwałego Maryi", tłum. i oprac. S. Kobielus, Maryi", tłum
Poznań 2012.

Fizjologi i Aviarium: średniowieczne traktaty o symbolice zwierzat, tłum. i oprac. S. Kobielus, Tyniec 2005

Teofil Prezbiter. Diversarum Artium Schedula. Średniowieczny zbiór przepisów o sztukach rozmaitych (tłum. i oprac.

S. Kobielus, Tyniec 1998 (wyd. 2 2009).

\section{Przewodniki}

Bania Z., Golonka J., Kobielus S.,

Częstochowa. La Madonna di Jasna Góra, Verona 1991.

Bania Z Golonka J., Kobielus S., Jasna Góra. Guide, Varsovie 1986.

Bania Z., Golonka J., Kobielus S., Jasna Góra. A Companion Guide, Warszawa 1986

Bania Z., Golonka J., Kobielus S., Jasna Góra. Das Paulinerkloster in Częstochowa und seine Sammlungen, Warschau 1986 (wyd. 2, Warszawa 1989).

Bania Z., Golonka J., Kobielus S., Jasna Góra. On the 6ooth Anniversary of the Sanctuary, Warszawa 1985.

Bania Z., Golonka J., Kobielus S., Jasna Góra przewodnik, Warszawa 1984

Bania Z., Kobielus S., Jasna Góra, Warszawa 1983

Bania Z., Golonka J., Kobielus S., Jasna Góra. $W 600$-lecie Sanktuarium, Warszawa 1983.

zbiory artykułów naukowych

Blask ciemności i światło niewiedzy, Ząbki 2015.

Dzieło sztuki - dzieło wiary. Przez widzialne do niewidzialnego, Ząbki 2002

\section{Tomiki poezji}

Gliniane dzbany, Ząbki 2017.

Kto użyczy łez trawom, Poznań 2013. Iskry z mokrych kamieni, Ząbki 2011. Zawiłości cienia, Ząbki 2010.

Wiersze $\mathrm{z}$ komentarzem, Tyniec 2007 Blask ciemności i światło niewiedzy, Tyniec 2005

iu wiatru, Tyniec 2000 W świetle niewiedzy, Tyniec 2000 Uciekajace krajobrazy, Tyniec 1997 Na wschód od duszy, Tyniec 1996. Zaśpiewać świattem, Warszawa 1992. Ilustrowane uogólnienia, Warszawa 1988. 